\title{
Relationship between manager credibility, strategic alignment and employee motivation
}

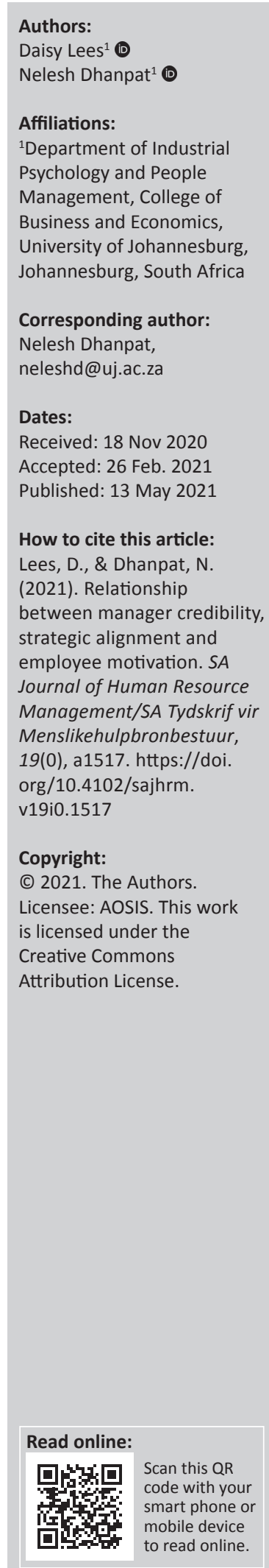

Orientation: In today's volatile and dynamic business environment, organisations need to continuously seek opportunities to increase their competitiveness through the human capital they employ. A sound understanding of factors that influence manager credibility, strategic alignment and employee motivation could enable organisations to proactively implement interventions that improve their competitive stance.

Research purpose: This study sought to examine the relationship between manager credibility, strategic alignment and motivation. The role of strategic alignment as a mediator between manager credibility and motivation was also explored.

Motivation for the study: Organisations need to have employees that are motivated and have a strategic fit. Managers play a significant role in fostering such. More so, it is essential to highlight the vital role that managers play in strategic alignment and employee motivation.

Research approach/design and method: A quantitative and cross-sectional research design was used. Non-probability sampling was employed, and data were collected by using established questionnaires from a sample of $N=3112$. Participants of the study are employed within various industries based in South Africa, Southern Africa and the United States of America. The data were analysed by using descriptive and inferential statistics.

Main findings: A positive relationship between all the variables were established. The three variables (manager credibility, strategic alignment and motivation) were found to be significantly positively correlated. Manager credibility influences motivation and strategic alignment. Manager credibility and strategic alignment were both found to have a statistically significant influence on employee motivation. The mediation analysis shows that strategic alignment plays a positive mediating role between manager credibility and motivation.

Practical/managerial implications: Recommendations are schematically presented in the form of a model, which, when implemented, have the potential to enhance employee motivation.

Contribution/value-add: The study provided insight into the influence of manager credibility and strategic alignment on employee motivation.

Keywords: motivation; credibility; strategic fit; managers; mediation analysis.

\section{Introduction}

Managers play a significant role in influencing organisational performance (Anzengruber, Goetz, Nold, \& Woelfle, 2017). The degree to which managers are proficient in creating relationships that inspire and psychologically align employees with organisational goals signifies their credibility (Ouakouak \& Ouedraogo, 2013; Veldsman \& Coetzee, 2014).

Manager credibility is related to employee strategic alignment and performance (Anitha, 2014; Esfahani, Ghasemi, \& Tabrizi, 2014; Ouakouak \& Ouedraogo, 2013; Veldsman \& Coetzee, 2014). The alignment between a company's operating context and strategy has significant implications for its sustainability and performance (Acur, Kandemir, \& Boer, 2012).

The concept of strategic alignment also refers to the degree to which employees understand and psychologically commit to executing the organisational strategy (Boswell, 2006; Ouakouak \& Ouedraogo, 2013). Although a manager's credibility plays an important role in employee strategic alignment, employee motivation is viewed as equally important (Belle, 2013; Hitchcock \& Stavros, 2017; Pokorny, 2013). Literature illustrates that motivated employees are efficient, creative, persist in challenging tasks and offer high levels of productivity (Victor \& Hoole, 2017). Employee motivation is cited as a contributing factor towards organisational credibility 
(Osmani, Rozan, Zaidi, \& Nilashi, 2014). Building credibility in organisations has been identified as one of the growing challenges in human capital management (Ahteela \& Vanhala, 2018; Clark \& Brown, 2015). Reputational damage, as well as devastating job and shareholder losses suffered at multinational companies such as Steinhoff, McKinsey and KPMG, demonstrates the need for organisations to promote credibility within their management teams and among all employees (Fraser, 2018; Govenden, 2018; Lou \& Yuan, 2019). This research highlights the effects of manager credibility and strategic alignment on employee motivation. In today's volatile organisational climate, characterised by uncertainty and ambiguity, there is much need to understand manager credibility and its links towards keeping employees motivated. The study expands on the relationships between manager credibility, strategic alignment and motivation and is empirical in nature. It is for this reason, the study seeks to make a contribution towards the literature. In addition, the collective effect of these variables has not been previously conducted.

\section{Literature review}

\section{Manager credibility}

Manager credibility refers to the degree to which managers are able to create employee experiences and relationships that inspire and psychologically align employees with organisational goals (Ouakouak \& Ouedraogo, 2013; Shaikh, 2019; Veldsman \& Coetzee, 2014). Manager credibility is also described as the ability to build relationships and team consensus that inspires employees to exert discretionary effort (Esfahani et al., 2014; Kubicek \& Cockram, 2019; Veldsman \& Coetzee, 2014; Yiing \& Ahmad, 2009). Manager credibility is built over time, through trustworthiness, and is characterised by how reliable, competent and consistent the behaviour of an individual is (Jiang \& Probst, 2015). Consistency, however, is unlikely to influence manager credibility if the manager constantly behaves in an uncaring, self-centred manner (Cunningham, 2000). Grasse (2014) equates manager credibility to a bank account that increases or decreases, respectively, through deposits of positive reinforcing words and actions or negative reinforcing words and actions.

Managers who are cognisant of the context in which they operate are able to identify with their organisations; have a deep self-awareness; are confident, optimistic and resilient; and have high moral characteristics that are viewed as credible and transformational (De Braine \& Dhanpat, 2019; Epitropaki, Kark, Mainemelis, \& Lord, 2017; Paulo \& Nunes, 2019).

Competence, sociability, consistency, empathy and vision are key aspects of leader-follower relationships (Seidel, Saurin, Tortorella, \& Marodin, 2019). It is important for managers to have an understanding of the inevitable role that their credibility plays towards influencing the achievement of common goals. The observed key constructs of manager credibility are trustworthiness, competence, empathy, selfawareness and consistency (Falcione, 1974; Falcione, McCroskey, \& Daly, 1977; Fogg \& Tseng, 1999; McCroskey \& Richmond, 1975; McCroskey \& Teven, 1999; Mccroskey \& Young, 1981).

\section{Credibility}

Credibility is regarded as the trustworthiness of a communicator or the source of information; it is based on how the receiver perceives the authenticity and competence of the communicator (Metzger \& Flanagin, 2013; Williams, Raffo, \& Clark, 2018). Credibility is characterised by how reliable, trustworthy and consistent the behaviour of an individual is perceived to be (Jiang \& Probst, 2015; Von der Ohe, Martins, \& Roode, 2004).

\section{Strategic alignment}

Strategic alignment refers to a linkage or fit; however, in both cases, it refers to the process of integrating and coordinating business strategy with internal strengths, external opportunities and threats (Schniederjans \& Cao, 2009). Strategic alignment highlights the organisation's focus in terms of understanding and managing forces within its operating context (Gatignon \& Xuereb, 1997). Previous management research credited organisations' competitive advantage on industry structure and internal structures (Chatzoglou, Diamantidis, Vraimaki, \& Vranakis, 2011; McAdam, Miller, \& McSorley, 2019; Mubarak \& Wan Yusoff, 2019). The industry-based perspective uses Porter's (1985) five forces framework, which includes barriers to entry, rivalry, buyers, suppliers and substitutes. The five forces are used to analyse the intensity of competition within an industry and its attractiveness or lack thereof in terms of profitability (Porter, 1985). Barney (1991) introduced a resource-based view that emphasises internal resources as the determinants of competitive advantage. Recent research argues that organisations can improve their competitive advantage, ability to respond to market dynamics and performance when strategic alignment is achieved (Acur et al., 2012; Chatzoglou et al., 2011; Shao, 2019; Street, Gallupe, \& Baker, 2018).

The principles of aligning strategy, financial outcomes, customers, internal processes and people aid comprehensive stakeholder involvement, which enables organisations to better link strategic decisions with operations. These principles allow managers to see the effect of selected strategies at operational level and improve the coordination of competencies, processes and performance (Sousa, De Melo, De Oliveira, \& Lourenço, 2020; Sudnickas, 2019).

\section{Motivation}

Employee motivation is the degree to which employees are intrinsically inspired by their work and the level to which they derive joy from simply doing the job (Baciu, 2018; Veldsman \& Coetzee, 2014). The manner in which employees take action, plan, coordinate and allocate resources 
represents how they identify with the organisation and is indicative of their level of motivation (Ndekugri \& Greene, 2020). Employee motivation is deemed to be an important aspect of organisational effectiveness and productivity (Kermally, 2005; Minhas \& Nirupama, 2017; Ndekugri \& Greene, 2020). It is argued that motivation is a management process that is aimed at encouraging employees to be more productive and effective for the advancement and sustainability of the organisation (Baciu, 2018; Nduka, 2016). Strategic awareness is a self-initiated activity; hence, managers need to understand the factors that determine and affect employee motivation (Strobel, Tumasjan, Spörrle, \& Welpe, 2017). Strategic awareness enables employees to become more proactive in scanning for risks and opportunities that enhance and protect the organisation's competitive advantage (Acur et al., 2012). Having a sound understanding of how to contribute, rather than simply knowing what the strategy of an organisation is, results in higher levels of motivation (Boswell, 2006; Madan, 2017; Ndekugri \& Greene, 2020).

\section{Strategic alignment in relationship with employee motivation}

To ensure growth and sustainability, management should develop and revise their strategies. However, to transform strategy into outcomes, they require their employees' follow-through and commitment (Gagné, 2018; Ouakouak \& Ouedraogo, 2013; Street et al., 2018). It has been argued that employees are most likely to take action and adapt their behaviours towards the achievement of strategic objectives when they understand how their efforts contribute towards organisational outcomes (Boswell, 2006; Copeland, 2013; McAdam et al., 2019).

Understanding organisational outcomes and how to contribute does not, however, guarantee that employees will be strategically aligned (Ouakouak \& Ouedraogo, 2013). Hence, it is important to be aware of the factors that motivate employees towards the attainment of desired outcomes (Gagné, 2018; McAdam et al., 2019). Research has found that companies with highly motivated employees achieve high performance (McAdam et al., 2019; Nduka, 2016; Ouakouak \& Ouedraogo, 2013; Street et al., 2018). As organisations are reliant on their employees' motivation to engage and contribute towards outcomes, it is important to identify factors that affect and enhance motivation (Hitchcock \& Stavros, 2017).

\section{Manager credibility in relationship with employee motivation}

Manager credibility has a significant influence on employee motivation (Esfahani et al., 2014). When manager credibility is low, the work environment is obstructed by pessimism and distrust; stakeholders therefore expect high levels of credibility and morals from organisation members (Abunyewah, Gajendran, Maund, \& Okyere, 2019; Esfahani et al., 2014; Kubicek \& Cockram, 2019).

\section{Manager credibility in relationship with strategic alignment and employee motivation}

The credibility of management can have positive or negative implications on organisational outcomes (Abunyewah et al., 2019; Jamal \& Abu Bakar, 2017; Kubicek \& Cockram, 2019; Men, 2012). The more credible the source of communication within organisations is deemed to be, the more able he or she is to influence stakeholders (Abunyewah et al., 2019; Metzger \& Flanagin, 2013). Employees who have positive perceptions of their manager's credibility are more likely to be strategically aware and proactive (Andrews, Boyne, Meier, O'Toole, \& Walker, 2012; Strobel et al., 2017). Strategic awareness stems from discretionary work performance (Ahmetoglu, Harding, Akhtar, \& Chamorro-Premuzic, 2015; Strobel et al., 2017). Discretionary effort is driven by motivation. Motivated employees engage in proactive behaviours that strive to improve the current and future position of the organisation (Copeland, 2013; De Vito, Brown, Bannister, Cianci, \& Mujtaba, 2016).

\section{Research questions}

Organisational efforts to anticipate factors that provide competitive leverage are ever present. In view of the theoretical background provided above, this study sought to answer the following research questions:

- What is the relationship between manager credibility, strategic alignment and employee motivation?

- Does strategic alignment play a mediating role in the relationship between manager credibility and employee motivation as an outcome variable?

The study assumes that strategic alignment plays a mediating role between manager credibility and employee motivation. Management research highlights the important role that managers play in strategic alignment and employee motivation (Acur et al., 2012; Barney, 1991). The model seeks to explore the relationships between the variables of manager credibility, strategic alignment and employee motivation. All the variables included in the model have been subject to previous empirical research.

\section{Method}

The study followed a quantitative, exploratory and cross-sectional approach. A quantitative approach allows objective testing of hypotheses as the researchers are able to distance themselves from their respondents (Quick \& Hall, 2015). A cross-sectional design was followed (Saunders, Lewis, \& Thornhill, 2007). The research sought to determine the extent to which manager credibility influences strategic alignment and employee motivation. The role of strategic alignment as a mediator, manager credibility as an independent variable and employee motivation as an outcome variable was also assessed. 


\section{Population, sampling procedure and sample size}

The study used secondary data that were obtained from a consultancy firm operating in the field of organisational development. The data were collected by using an online, secure platform in 2016 and 2017 from 20 companies - 18 based in South Africa, 1 in Southern Africa and 1 in the United States of America. The companies operate within the education, financial, information technology, manufacturing, medical, non-profit, property, provincial government, regulatory, oil and gas sectors. A non-probability, purposive sampling technique was used. Non-probability sampling allows a researcher to select participants, based on convenience and representativeness of the characteristics being studied (Creswell, 2012, p. 145). Most of the respondents $(38.3 \%)$ were in the age group of 26-35 years, followed by $36-50$ years of age $(29.3 \%)$ and $21-25$ years old $(22.2 \%)$. Individuals in the 50 years and older age group were at $7.7 \%$, whereas those younger than 21 years made up $2.5 \%$ of the sample population. Men made up (52.6\%) of the population in comparison with $40.2 \%$ women. The majority of the respondents held a Grade 12 matriculation certificate (39.8\%), followed by a national diploma $(22.6 \%)$, and postgraduate degree (14\%).

\section{Measuring instrument}

The instruments that were selected for this study were manager credibility, strategic alignment and motivation (Veldsman \& Coetzee, 2014).

\section{Manager credibility}

Manager credibility was measured by means of five items. An example of an item measuring credibility is 'Does your manager treat everyone with respect?' The items were measured on a four-point Likert scale from 1 (Never) to 4 (All the time). Manager credibility reported a Cronbach's alpha coefficient of 0.83 (time 1) and 0.78 (time 2) (Veldsman, 2017; Veldsman \& Coetzee, 2014). The current study reported a Cronbach's alpha of 0.92, which shows a high level of credibility as indicated by Creswell (2012).

Strategic alignment items were measured on a four-point Likert scale, from 1 (Never) to 4 (All the time). 'How well do you know what is expected of you at work?' is an example of an item on this scale. Strategic alignment reported Cronbach's alpha coefficients of 0.73 (time 1) and 0.67 (time 2) (Veldsman, 2017; Veldsman \& Coetzee, 2014). The Cronbach's alpha for this study is reported as 0.69 , which is an acceptable level of reliability, according to Hair, Black, Babin and Anderson (2013).

Motivation items were similarly measured on a four-point Likert scale, from 1 (Never) to 4 (All the time). An item example is 'How often do you feel compelled to initiate activities to make things better in your work environment?' Motivation reported Cronbach's alpha coefficients of 0.81 (time 1) and 0.76 (time 2) (Veldsman, 2017; Veldsman \& Coetzee, 2014). The Cronbach's alpha for this study is reported as 0.59 , which is an acceptable level of reliability, as indicated by Creswell (2012) and Hair et al. (2013).

The consultancy firm that collected the data used predesigned questionnaires. The questionnaires were uploaded onto a secure, online platform, with a covering letter that stated the purpose of the research. The questionnaire, which consisted of biographical information, as well as items measuring credibility, strategic alignment and motivation, was designed by Veldsman and colleagues from Mindset Management and was validated by Veldsman and Coetzee (2014). Each questionnaire included a note that invited respondents to participate voluntarily, with the assurance that their participation would be anonymous and treated confidentially. Participants were assured that they could opt out at any time without any negative consequences.

\section{Statistical analysis}

Data from the questionnaires were statistically interpreted by using the Statistical Package for the Social Sciences (SPSS) computer software program, version 25 . The descriptives of the measuring instruments are reported. Descriptive statistics were conducted. Internal consistency and reliability were determined through exploratory factor analysis. Inferential statistics were used to test the relationships between constructs in answering the research questions. Research Question 1 is answered through Spearman's correlation, which is utilised to determine the relationship between variables (Pallant, 2010). Simple multiple regression analysis has been used with a mediation model to test Research Question 2 (strategic alignment as a mediator and the prediction of motivation by means of manager credibility and strategic alignment).

\section{Descriptive statistics}

\section{Manager credibility}

Responses for the manager credibility scale indicated results ranging from $M=2.67$ to $M=3.19$. Item MC2 ('Does your manager treat everyone with respect?') scored a high mean value (3.19), suggesting the agreeability that managers do treat everyone with respect most of the time. On the contrary, item MC5 ('Does your manager inspire you by his or her example?') was perceived by employees that only some of the time they feel inspired by their manager.

To test normality, the data set was also tested for skewness and kurtosis. A negative skewness of -0.473 was reported, indicating that most of the responses were agreeable. Kurtosis of the data was recorded at -0.723 , indicating that the data were not normally distributed, resulting in a graph with lighter tails and a flat peak (Hair et al., 2013). The results may have been influenced by social desirability, where respondents tend to answer positively to questions they deem sensitive or when they do not fully trust that the survey is anonymous (Fisher, 1993). 


\section{Strategic alignment}

The means for strategic alignment (SA) ranged from $M=$ 2.85 to $M=3.42$. Item SA1 ('How well do you know what is expected of you at work?') scored a high mean value (3.42), suggesting that employees perceived that most of the time they knew what was expected of them at work. However, on the item SA5 ('Does your manager set realistic and achievable goals for your business unit or team?'), most of the respondents did not believe that the manager was setting realistic goals most of the time, indicated by a mean of 2.85. In the test for normality on strategic alignment, the data showed a skewness of -0.663 , indicating that most responses were agreeable (Hair et al., 2013). The kurtosis of the data was 0.468 , indicating that the data were not normally distributed.

\section{Motivation}

The results for motivation indicated that mean responses ranged from $M=2.90$ to $M=3.43$. Item W2 ('How often does your team put in extra effort to get the job done?') scored a high mean value (3.43), suggesting that employees perceived their team to put in extra effort occasionally. Item W5 ('Does your job motivate you to do more than what is required of you?') scored a low mean value of 2.90, suggesting that employees perceive that their job hardly ever motivates them to do more than what is required. The data obtained for motivation were also tested for skewness and kurtosis. Skewness was recorded at -0.515 , indicating that most responses were agreeable (Hair et al., 2013). The kurtosis of the data was 0.454 , which indicates that the data were not normally distributed (Hair et al., 2013).

\section{Construct validity}

To review the construct validity of the instruments, exploratory factor analysis was conducted according to the guidelines proposed by Pallant (2010). The Pearson's correlation coefficient analysis was used to determine if the variables were related, and how strongly they are related (Pallant, 2010, p. 128). The size of the coefficient value indicates the strength of the relationship, with $r>0.30$ being acceptable (Pallant, 2010, p. 128). Kaiser-Meyer-Olkin (KMO) measure of sampling adequacy and Bartlett's test of sphericity were performed on all three instruments. The $\mathrm{KMO}$ test is a measure of how suited a data set is for factor analysis; the test indicates the proportion of variance in the variables that may be caused by other underlying factors (Tabachnick \& Fidell, 2007, p. 620). Values close to 1.0 indicate that factor analysis is suited for the data set, values of 0.6 and above are considered sufficient and less than 0.5 is questionable (Tabachnick \& Fidell, 2007, p. 620). Bartlett's test measures the overall significance of all the correlations in a correlation matrix. Values of $<0.5$ of the significance level show that factor analysis is suitable (Hair et al., 2013). In addition to the KMO and Bartlett's tests, communalities and item loadings were analysed. Communalities indicate the extent to which an item is correlated with all other items. Factor loadings above 0.3 are deemed acceptable
(Pallant, 2010). To determine the number of factors to retain, factor extraction was conducted through Kaiser's criterion and Cattell's scree test. The number of factors that are retained indicates the interrelationships within a set of variables.

\section{Ethical considerations}

Ethical permission for this study was obtained from IPPM Research Ethics Committee, ethical clearance number: IPPM-2019-351 (M).

\section{Results}

\section{Frequency analysis}

\section{Manager credibility}

The results showed that most of the respondents perceived that their manager was credible. This was indicated by $39 \%$ of the respondents, believing that their manager acted in a way that was consistent with organisational values most of the time. However, when the respondents were asked if they were inspired by their manager, only $32 \%$ of them indicated that they were inspired most of the time. All items for manager credibility had a correlation greater than 0.30 . The KMO of sampling adequacy for manager credibility was 0.885 , which is above the recommended 0.60 and the Bartlett's test of sphericity was significant at $p=0.000$. The communalities for manager credibility were above 0.30 and explain the variance in manager credibility adequately (Pallant, 2010). The Kaiser's criterion and total explained variance for manager credibility showed one initial eigenvalue above 1 , signifying a single factor with a total explained variance of $75.15 \%$, which is acceptable.

\section{Strategic alignment}

The results showed that most of the respondents indicated that most of the time they were strategically aligned. When the respondents were asked how well they knew what was expected of them at work, 53\% responded that they did so all of the time. When the respondents were asked if they understood the vision of their organisation, $42 \%$ indicated that they did to a great extent. The correlation coefficients were all more than 0.30 , the KMO measure of sampling adequacy was 0.755 and the Bartlett's test of sphericity was statistically significant as it was smaller than 0.05 . The extracted communalities of each item selected were at an acceptable level of above 0.30 for each item. Kaiser's criterion and total explained variance showed one initial eigenvalue above 1, signifying that a single factor with a total explained variance of $44.97 \%$ for strategic alignment was satisfactory.

\section{Motivation}

The results for motivation indicated that most of the respondents were motivated. This was shown by $52 \%$ of the respondents, indicating that every now and then they felt compelled to initiate activities that made things better within their work environment. However, when the respondents were asked if their job motivated them, only $36 \%$ indicated 
that it did every now and then. The correlation coefficients ranged from 0.18 to 0.27 . All the variables had a positive result, indicating that an increase in one variable will lead to an increase in the other variable.

Sampling adequacy was 0.664 , and the Bartlett's test of sphericity was statistically significant, indicated by a $p=0.000$ value. The communalities for motivation showed that the extracted communalities of each item were at an acceptable level of above 0.30 . Kaiser's criterion and total variance explained showed two initial eigenvalues above 1, namely 1.912 and 1.077, and these two factors explain a cumulative variance of $59.78 \%$.

\section{Analysis of relationships between manager credibility, strategic alignment and motivation}

Spearman's correlation coefficient (two-tailed; Pallant, 2010, p. 103) was used to address the Research Question 1 ('What is the relationship between manager credibility, employee motivation and strategic alignment?').

The results shown in Table 1 indicate that there was a significant positive correlation between the three variables (manager credibility, strategic alignment and motivation) at the $90 \%$ level of significance. Medium-to-large correlation effects were noted.

\section{Linear regression}

To answer Research Question 2, a simple multiple regression analysis was employed to test the prediction of motivation by means of manager credibility and strategic alignment.

The simple multiple regression reported in Table 2 indicates that manager credibility and strategic alignment explain $31.7 \%$ of the variance in motivation $(F=724.127$; $2: 3109, p=0.000$ ). Both predictor variables (manager credibility and strategic alignment) entered the prediction at the $99 \%$ level of confidence. Manager credibility predicted motivation at $17.9 \%(t=0.9 .997 ; p=0.000)$. For every unit that manager credibility increased, motivation increased by 0.179 points. Strategic alignment predicted

TABLE 1: Spearman's correlation coefficient on motivation, strategic alignment and manager credibility $(N=3112)$.

\begin{tabular}{lccc}
\hline Variable & Motivation & Manager credibility & Strategic alignment \\
\hline Motivation & 1.000 & $0.432 \dagger$ & $0.531 \dagger$ \\
& - & 0.000 & 0.000 \\
Manager credibility & $0.432 \dagger$ & 1.000 & $0.559 \dagger$ \\
& 0.000 & - & 0.000 \\
Strategic alignment & $0.531 \dagger$ & $0.559 \dagger$ & 1.000 \\
& 0.000 & 0.000 & - \\
\hline
\end{tabular}

$\dagger$, Correlation is significant at the 0.01 level (two-tailed). motivation at $44.3 \%(t=0.24 .682 ; p=0.000)$. For every unit that strategic alignment increased, motivation increased by 0.443 points.

\section{Regression model exploring the mediating role of strategic alignment}

In answering the second research question 'Does strategic alignment play a mediating role in the relationship between manager credibility and employee motivation as an outcome variable?', standard multiple regression analysis was performed through SPSS by using PROCESS macrobootstrapping with manager credibility as an independent variable, strategic alignment as the mediator and motivation as the dependent variable. Three regression paths were tested; the indirect effect of strategic alignment as a mediator is illustrated in Figure 1 (Hayes, 2009; Valeri \& Vanderweele, 2013).

Figure 1 illustrates path $\mathrm{c}$ as the predictor to the outcome variable (Manager Credibility-Motivation). Path a represents the predictor variable to the mediator variable (Manager Credibility - Strategic Alignment) and path $\mathrm{b}$ represents the mediator variable to the outcome variable (Strategic Alignment - Motivation).

Figure 1 indicates a significant positive direct effect of manager credibility on motivation $\left(R^{2}=0.3179 ; F=7241267\right.$ $(2 ; 3109) ; p<0.000)$. With the bootstrapping confidence levels above zero, between lower level confidence interval (LLCI) of 0.2257 and 0.2618 , the model is significant at the 0.05 level of significance. The size of the mediation is calculated by dividing the indirect effect $(0.1420)$ by the total effect (0.2437). The partial mediation of strategic alignment accounts for $58.3 \%$ of the variance in motivation

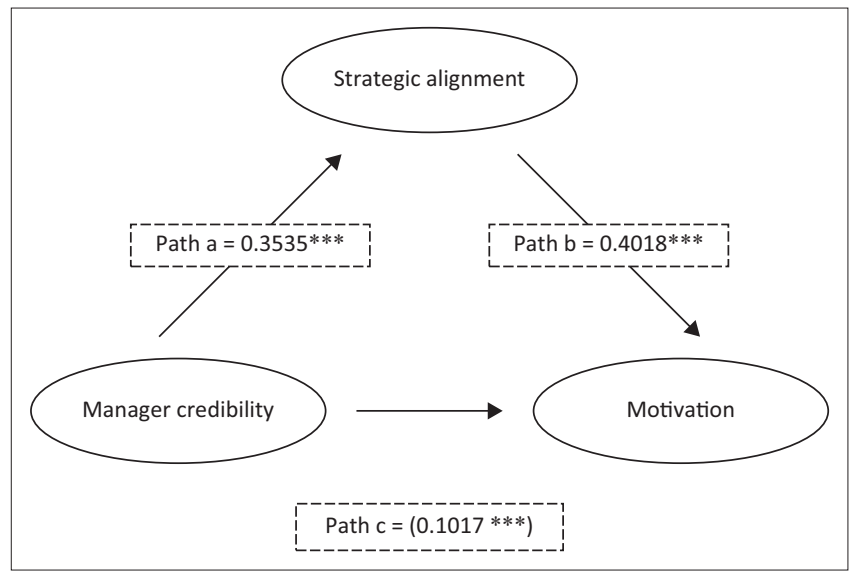

$* p<0.05, * * p<0.01, * * * p<0.001$.

FIGURE 1: Mediation model - predictor variable (manager credibility), outcome variable (motivation) and mediator variable (strategic alignment).

TABLE 2: Standard multiple regression: Manager credibility and strategic alignment as the independent variables and motivation as the dependent variable.

\begin{tabular}{lcccccccc}
\hline $\begin{array}{l}\text { Dependent variable: } \\
\text { Motivation }\end{array}$ & $\boldsymbol{R}$ & $\boldsymbol{R}^{2}$ & Adjust $\boldsymbol{R}^{2}$ & $\boldsymbol{F}(\boldsymbol{d} f)$ & $\boldsymbol{p}$ & $\boldsymbol{B}$ unstandardised & $\boldsymbol{B}$ standardised & $\boldsymbol{T}$ \\
\hline & 0.564 & 0.318 & 0.317 & $724.127(2: 3109)$ & 0.000 & - & - \\
\hline
\end{tabular}


as an outcome variable. The direct effect of manager credibility on motivation is $41.7 \%$.

Path c results show that manager credibility is a statistically significant predictor of motivation at $35.35 \%(B=0.3535$; $p=0.000)$. A unit of increase in manager credibility will increase motivation by 0.3535 points. Path a indicates a statistically significant, positive direct relationship between manager credibility and strategic alignment at $10.17 \%$ $(B=0.1017 ; p=0.000)$. A unit of increase in manager credibility will increase strategic alignment by 0.1017 points. Path $b$ results also indicate that strategic alignment has a statistically significant positive prediction of motivation at $40.18 \%(B=0.4018 ; p=0.000)$. A unit of increase in strategic alignment will increase motivation by 0.4018 points.

The results support the mediational research question that asked whether motivation is partially mediated by strategic alignment. The effect of manager credibility on motivation increased from $35.35 \%$ to $40.18 \%$ when strategic alignment was included.

\section{Discussion}

\section{Descriptive statistics - Manager credibility, strategic alignment and motivation}

An average mean value of 2.91 (maximum $=4$ ) for manager credibility was obtained. This indicated that most of the respondents perceived their managers to be credible most of the time.

Employees who perceive their managers as credible remain committed to the organisation, which enhances their loyalty (Esfahani et al., 2014). With regard to strategic alignment, an average mean value of 3.20 (maximum $=4$ ) was obtained. This suggests that the majority of the respondents perceived that most of the time they were cognisant of the organisation's strategic pursuits. Employees who remain aligned with the priorities of the organisation are likely to maintain high levels of engagement (Biggs, Brough, \& Babour, 2014). In terms of motivation, the average mean value achieved was 2.89 (maximum $=4$ ), suggesting that employees perceived themselves to be occasionally motivated. These results support the arguments by Copeland (2013) and Ndekugri and Greene (2020), who cite that discretionary effort is driven by employee motivation. Motivated employees are more likely to engage in proactive strategic scanning behaviours that enhance organisational sustainability and performance.

To determine the reliability of the results, the Cronbach's alpha test was used as a measurement.

The Cronbach's alphas reported for the variables were 0.90 for manager credibility, 0.60 for motivation and 0.70 for strategic alignment. According to Hair et al. (2013), these alphas are regarded as acceptable. Motivation achieved a value below 0.70 . Measures that have a small number of items (under 10, such as motivation in this case) will yield lower reliability scores. Therefore, it is essential to assess the mean inter-item correlations to confirm internal consistency. Upon inspection of the mean inter-item correlation, the value achieved was 0.24 , which is within the cut-off point of 0.40 (Pallant, 2010).

Exploratory factor analysis was carried out on the three variables. Exploratory factor analysis is used to simplify data by reducing the number of variables in regression models (Creswell, 2012, p. 15). Explanatory factor analysis is also used to verify the construction research scales (Creswell, 2012, p. 15). Manager credibility showed a factor of one total explained variable of $75.15 \%$. This shows that the one factor could be used to explain all other variables. Strategic alignment showed a factor of one total explained variance of $44.97 \%$. A proportion of explained variance less than $50 \%$ is acceptable in social sciences (Hair et al., 2013). Motivation showed a factor of two total explained variables with a cumulative variance of $59.78 \%$. This indicated that two factors for motivation can be used to explain the variance in all other variables.

\section{Spearman's correlation coefficient}

Because of the non-normal distribution of data, Spearman's correlation coefficient (two-tailed) was used to address Research Question 1 ('What is the relationship between manager credibility, strategic alignment and employee motivation?'). The analysis showed that there was a positive relationship between all the variables. Manager credibility, strategic alignment and motivation were shown to be significantly positively correlated. Manager credibility had a medium effect on motivation. This suggests that as manager's credibility increases, employees are more likely to remain motivated. In terms of strategic alignment, a large effect was not found. It is likely that as employees feel congruent towards the organisation's goals and pursuits, they will remain motivated. This result supports those of Lyubovnikova et al. (2017) and Coetzee and Veldsman (2013), who argue that a leader who is regarded as credible will have a positive influence on an employee's strategic alignment to organisational goals.

Esfahani et al. (2014) outline that a manager's credibility has an influence on the motivation of employees. The findings indicate that a lack of manager credibility will adversely affect employee motivation. Employees will not willingly exert discretionary effort, such as volunteering to perform tasks, without being asked, or be compelled to initiate activities that improve or optimise organisational efficiencies and effectiveness.

To further explore the relationship between all the variables, standard multiple regression was conducted. The results indicated that manager credibility influences motivation. This was shown by a significant regression $F=(1,3110)=$ $701805, p<0.001, R^{2}=0.184$. The coefficient results indicated that motivation increases by 0.009 points when manager credibility increases by a unit. Manager credibility was also 
shown to influence strategic alignment $F=(1,3110)=1454.46$, $p<0.001, R^{2}=0.319$. The coefficient regression results show that strategic alignment increases by 0.009 points when manager credibility increases by a unit. Regression analysis with manager credibility and strategic alignment as predictors of employee motivation was also carried out. The results indicate that manager credibility and strategic alignment have a significant influence on employee motivation at $F=(2,3109)=724127, p<0.001, R^{2}=0.318$.

Motivation increases by 0.010 points when manager credibility increases by a unit. Strategic alignment contributed $16 \%$ towards motivation as an outcome variable $(t=24.68 ; p=0.000)$, with a significance value of $<0.5$. By every unit that strategic alignment increases, motivation increases by 0.016 points. The beta results indicate that strategic alignment has the largest unique contribution to motivation $(\beta=0.443)$. This finding supports research conducted by Andrews et al. (2012) and Strobel et al. (2017), who argue that manager credibility influences the motivation of employees and strategic alignment.

\section{Regression model exploring the mediating role of strategic alignment}

A regression analysis was performed to address Research Question 2 ('Does strategic alignment play a mediating role in the relationship between manager credibility and employee motivation as an outcome variable?'). Standard multiple regression analysis was performed through SPSS by using bootstrapping with manager credibility as an independent variable, strategic alignment as the mediator and motivation as the dependent variable (Hayes, 2009; Valeri \& Vanderweele, 2013). Three regression paths were tested, and the results showed that strategic alignment partially mediated the role between manager credibility and motivation. The effect of manager credibility on motivation decreased from $24.37 \%$ to $10.17 \%$ when strategic alignment was included (Valeri \& Vanderweele, 2013). The results also showed that strategic alignment was positively related to manager credibility and motivation. This indicates that the model used can reliably explain the relationship between manager credibility, strategic alignment and motivation.

\section{Limitations of the study}

The study used a self-measurement tool, which is prone to positive rating bias (Van de Mortel, 2008). This may have contributed towards the non-normal distribution of data. Many respondents (66\%) did not indicate their ethnicity, and $19 \%$ were from the same ethnic group. The study was also conducted in the financial industry, and thus the findings of the study need to be interpreted with caution.

\section{Recommendations and managerial implications}

The study provided insights into the relationships between manager credibility, strategic alignment and motivation in the work environment. Good corporate reputation is built and maintained by the behaviour of organisational stakeholders. Consistency, trustworthiness, respect, empathy and competence are essential for persons who are in management or leadership roles. The findings in this study support the notion that there is a significant relationship between manager credibility, strategic alignment and motivation. The findings also showed that an increase in any one of these variables would result in an increase in the other. Strategic alignment was shown to play a relatively significant mediatory role on manager credibility in influencing employee motivation.

Based on the results of manager credibility and strategic alignment, recommendations are schematically presented in the form of a model (see Figure 2), which, when implemented, has the potential to enhance employee motivation. It is pertinent that management and human resource (HR) practitioners are cognisant of the challenges presented and recommendations put forward. Collectively, the results indicate that employees remaining motivated hinge upon the credibility of managers and employees' strategic fit to the organisation. These factors are likely to ensure proactive behaviours and that employees take greater initiative, lending themselves to enhanced motivation.

Human resource practitioners can influence manager credibility, strategic alignment and motivation through the development and implementation of manager competency training and development programmes that are effectively

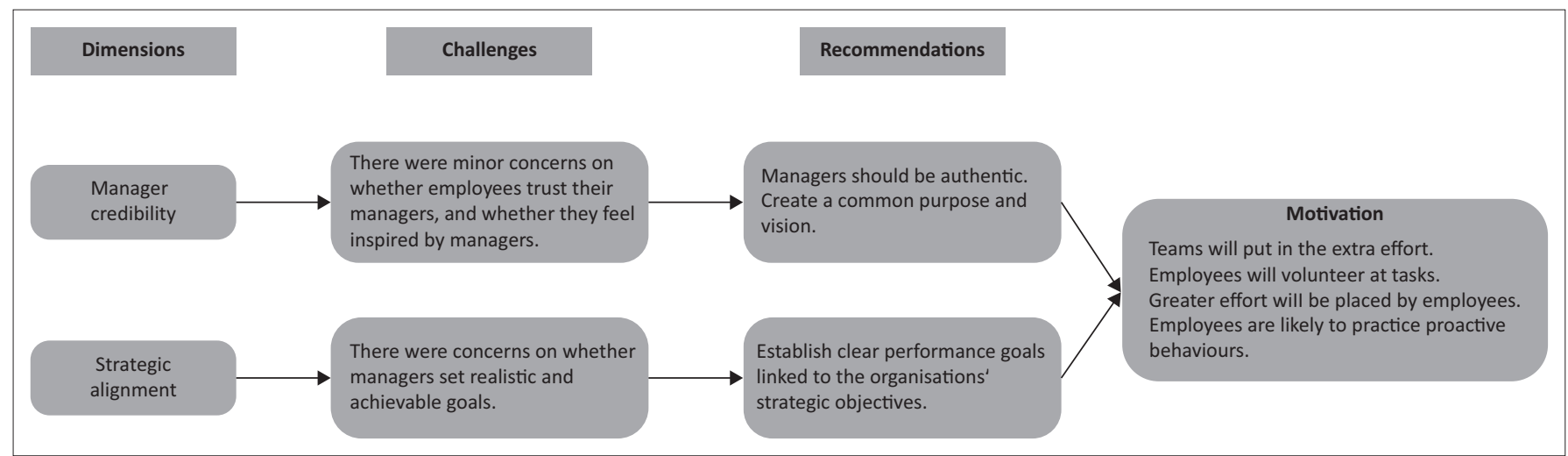

FIGURE 2: Recommendations based on manager credibility and strategic alignment on motivation. 
designed to model credible actions and behaviours. The researcher hopes to encourage organisations to move beyond best practice and mechanistic approaches to management towards more organic structures that enable proactive behaviours, creativity and empowered decisionmaking. Extant theory indicates that organic structures are instrumental in enhancing organisational sustainability and strategic alignment. Human resource practitioners must equally be prepared to implement HR change management initiatives that can be aligned to increasingly dynamic and complex environments.

The study has contributed to management research by showing the effects of the relationships between manager credibility, strategic alignment and motivation. In quantitative research, the self-measurement tool can be prone to positive self-rating bias and respondents are limited to questions posed by the researcher (Van de Mortel, 2008). Future research could consider a qualitative approach into the different factors that relate to the variables discussed in this study.

\section{Recommendations for future research}

To minimise aspects of social desirability, a qualitative casebased approach into the variables discussed in this study could be considered. It is also recommended that additional research be conducted to confirm the initial findings on the mediatory effect of strategic management on employee motivation. To validate the measuring instruments within a South African context, further research can be conducted, as the instruments did not present the same structures as the initial research carried out by Veldsman (2017).

\section{Conclusion}

The study revealed valuable insights on the relationship of manager credibility and intra-team effectiveness as predictors of motivation in the workplace. Treating employees in a trusting, consistent and respectable manner can establish a manager's credibility, an essential attribute in leading inspired and effective teams that contribute positively towards accomplishing organisational objectives. The interplay with intra-team effectiveness revealed that team motivation levels can be enhanced owing to both manager credibility and team effectiveness.

\section{Acknowledgements Competing interests}

The authors declare that they have no financial or personal relationships that may have inappropriately influenced them in writing this article.

\section{Authors' contributions}

This manuscript is based on the master's dissertation of the first author under the supervision of the second author.
D.L. was responsible for conceptualising and writing the manuscript and N.D. assisted with data analysis.

\section{Funding information}

This research received no specific grant from any funding agency in the public, commercial or not-for-profit sectors.

\section{Data availability}

Data sharing is not applicable to this article as no new data were created or analysed in this study.

\section{Disclaimer}

The views and opinions expressed in this article are those of the authors and do not necessarily reflect the official policy or position of any affiliated agency of the authors.

\section{References}

Abunyewah, M., Gajendran, T., Maund, K., \& Okyere, S.A. (2019). Linking information provision to behavioural intentions: Moderating and mediating effects of message clarity and source credibility. International Journal of Disaster Resilience in the Built Environment, 11(1), 100-118. https://doi.org/10.1108/IJDRBE-08-2019-0059

Acur, N., Kandemir, D., \& Boer, H. (2012). Strategic alignment and new product development: Drivers and performance effects. Journal of Product Innovation Management, 29(2),304-318. https://doi.org/10.1111/j.1540-5885.2011.00897.x

Ahmetoglu, G., Harding, X., Akhtar, R., \& Chamorro-Premuzic, T. (2015). Predictors of creative achievement: Assessing the impact of entrepreneurial potential, perfectionism, and employee engagement. Creativity Research Journal, 27(2), 198-205. https://doi.org/10.1080/10400419.2015.1030293

Ahteela, R., \& Vanhala, M. (2018). HRM bundles and organizational trust. Knowledge \& Process Management, 25(1), 3-11. https://doi.org/10.1002/kpm.1561

Andrews, R., Boyne, G.A., Meier, K.J., O’Toole, L.J., \& Walker, R.M. (2012). Vertical strategic alignment and public service performance. Public Administration, 90(1) 77-98. https://doi.org/10.1111/j.1467-9299.2011.01938.x

Anitha, J. (2014). Determinants of employee engagement and their impact on employee performance. International Journal of Productivity and Performance Management, 63(3), 308-323. https://doi.org/10.1108/IJPPM-01-2013-0008

Anzengruber, J., Goetz, M.A., Nold, H., \& Woelfle, M. (2017). Effectiveness of managerial capabilities at different hierarchical levels. Journal of Managerial Psychology, 32(2), 134-148. https://doi.org/10.1108/JMP-12-2015-0451

Baciu, L.E. (2018). Expectancy theory explaining civil servants' work motivation. Evidence from a Romanian City Hall. The USV Annals of Economics and Public Administration, 17(2[26]), 146-160. Retrieved from http://www.annals.seap.usv. ro/index.php/annals/article/viewFile/1015/887

Barney, J. (1991). Firm resources and sustained competitive advantage. Journal of Management, 17(1), 99-120. https://doi.org/10.1177/014920639101700108

Belle, N. (2013). Experimental evidence on the relationship between public service motivation and job performance. Public Administration Review, 73(1), 143-153. https://doi.org/10.111/j.1540-6210.2012.02621.x.Experimental

Biggs, A., Brough, P., \& Babour, J. (2014). Strategic alignment with organizational priorities and work engagement: A multi-wave analysis. Journal of Organizational Behavior, 35(3), 301-317. https://doi.org/10.1002/job

Boswell, W. (2006). Aligning employees with the organization's strategic objectives: Out of 'line of sight', out of mind. International Journal of Human Resource Management, 17(9), 1489-1511. https://doi.org/10.1080/09585190600878071

Chatzoglou, P.D., Diamantidis, A.D., Vraimaki, E., \& Vranakis, S.K. (2011). Aligning IT, strategic orientation and organizational structure. Business Process Management Journal, 17(4), 663-687. https://doi.org/10.1108/14637151111149474

Clark, C., \& Brown, J.A. (2015). Multinational corporations and governance effectiveness: Toward a more integrative board. Journal of Business Ethics, 132(3), 565-577. https://doi.org/10.1007/s10551-014-2358-6

Coetzee, M., \& Veldsman, D. (2013). Organizational values in relation to lived values experiences in the South African financial sector. African Journal of Business Management, 7(7), 480-489. https://doi.org/10.5897/AJBM2013.1606

Copeland, D. (2013). Examining the impact of employees' perceived understanding of strategy on engagement. Doctoral thesis. Pepperdine University. Retrieved from https://0-search-proquest-com.ujlink.uj.ac.za/business/docview/1426623048/F1 8912E9FF54577PQ/1?accountid=13425

Creswell, J.W. (2012). Educational research: Planning, conducting, and evaluating quantitative and qualitative research. Boston, MA: Pearson Education Inc.

Cunningham, J.B. (2000). Trust and the design of work: Complementary constructs in satisfaction and performance. Human Relations, 53(12), 1575-1591. https://doi. org/10.1177/00187267005312003 
De Braine, R., \& Dhanpat, N. (2019). Investigating the role of job resources in predicting employees' strategic connection to the organisation. In International

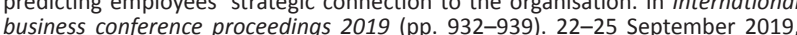
business conference proceedings 2019 .
North-West University, Hermanus, SA.

De Vito, L., Brown, A., Bannister, B., Cianci, M., \& Mujtaba, B.G. (2016). Employee motivation based on the hierarchy of needs, expectancy and the two-factor theories applied with higher education employees. International Journal of Advances in Management, Economics and Entrepreneurship, 3(1), 20-32. Advances in Management, Econc
Retrieved from www.ijamee.info

Epitropaki, O., Kark, R., Mainemelis, C., \& Lord, R.G. (2017). Leadership and followership identity processes: A multilevel review. The Leadership Quarterly, 28(1), 104-129. https://doi.org/10.1016/j.leaqua.2016.10.003

Esfahani, A.N., Ghasemi, R.A., \& Tabrizi, A.T. (2014). The relationship between management credibility and affective commitment in consultant engineering
Firms: Evidence from Iranian organizations. Procedia - Social and Behaviora Sciences, 143(1), 947-952. https://doi.org/10.1016/j.sbspro.2014.07.532

Falcione, R.L. (1974). The factor structure of source credibility scales for immediate superiors in the organizational context. Communication Studies, 25(1), 63-66. https://doi.org/10.1080/10510977409367770

Falcione, R.L., McCroskey, J.C., \& Daly, J.A. (1977). Job satisfaction as a function of employees' communication apprehension, self-esteem, and perceptions of their immediate supervisors. Annals of the International Communication Association 1(1), 363-375. https://doi.org/10.1080/23808985.1977.11923692

Fisher, R.J. (1993). Social desirability bias and the validity of indirect questioning social desirability bias and the validity of indirect questioning. Journal of Consumer Research, 20(2), 303-315. https://doi.org/10.2307/2489277

Fogg, B.J., \& Tseng, T. (1999). The elements of computer credibility. In Proceedings of the SIGCHI conference on Human Factors in Computing Systems (pp. 80-87). California, 15-20 May 1999. Retrieved from http://research.cs.vt.edu/ns/ cs5724papers/7.hciincontext.socpsyc.fogg.elements.pdf

Fraser, J. (2018). KPMG SA sheds 400 staff in battle for survival. Retrieved from http:// www.themessenger.global/Post/details/30371-kpmg-sa-sheds-400-staff-inbattle-for-s

Gagné, M. (2018). From strategy to action: Transforming organizational goals into organizational behavior. International Journal of Management Reviews, 20(S1) S83-S104. https://doi.org/10.1111/ijmr.12159

Gatignon, H., \& Xuereb, J.M. (1997). Strategic orientation of the firm and new product performance. Journal of Marketing Research, 34(1), 77-90. https://doi.org/ $10.1177 / 002224379703400107$

Govenden, R. (2018). Nothing fails like success. HR Future, 2018(4), 24-27. https:// journals.co.za/doi/pdf/10.10520/EJC-dca4e6576

Grasse, N.J. (2014). City managers' leadership credibility: Explaining the variations of self-other assessments. Public Administration Quarterly, 38(4), 544-572.

Hair, J.F., Black, C., Babin, B.J., \& Anderson, R.E. (2013). Multivariate data analysis. Upper-Saddle River, NJ: Prentice Hall.

Hayes, A.F. (2009). Beyond Baron and Kenny: Statistical mediation analysis in the new millennium. Communication Monographs, 76(4), 408-420. https://doi.org/10. 1080/03637750903310360

Hitchcock, B.J.A., \& Stavros, J.M. (2017). Organizational collective motivation. $O D$ Practitioner, 49(4), 28-36.

Jamal, J., \& Abu Bakar, H. (2017). Revisiting organizational credibility and organizational reputation - A situational crisis communication approach. SHS Web of Conferences, 33, 1-7. https://doi.org/10.1051/shsconf/20173300083

Jiang, L., \& Probst, T.M. (2015). Do your employees (collectively) trust you? The importance of trust climate beyond individual trust. Scandanavian Journal of Management, 31(4), 426-535. https://doi.org/10.1016/j.scaman.2015.09.003

Kermally, S. (2005). Gurus on people management. Chicago, IL: Thorogood Publishing.

Kubicek, J., \& Cockram, S. (2019). How to become someone worth following. Hoboken, $\mathrm{NJ}$ : John Wiley \& Sons.

Lou, C., \& Yuan, S. (2019). Influencer marketing: How message value and credibility affect consumer trust of branded content on social media. Journal of Interactive Advertising, 19(1), 58-73. https://doi.org/10.1080/15252019.2018.1533501

Lyubovnikova, J., Legood, A., Turner, N., \& Mamakouka, A. (2017). How authentic leadership influences team performance: The mediating role of team reflexivity. Journal of Business Ethics, 141(1), 59-70.

Madan, S. (2017). Moving from employee satisfaction to employee engagement International Journal of Research in Commerce \& Management, 8(6), 46-51. Retrieved from http://ijrcm.org.in/

McAdam, R., Miller, K., \& McSorley, C. (2019). Towards a contingency theory perspective of quality management in enabling strategic alignment. International Journal of Production Economics, 207, 195-209. https://doi.org/10.1016/j.ijpe.2016.07.003

McCroskey, J.C., \& Richmond, P.V. (1975). The effects of communication apprehension on the perception of Peers. Western Speech Communication, 40(1), 14-21. https://doi.org/10.1080/10570317609373881

McCroskey, J.C., \& Teven, J.J. (1999). Goodwill: A re-examination of the construct and its measurement. Communications Monographs, 66(1), 90-103. https://doi. org/10.1080/03637759909376464

Mccroskey, J.C., \& Young, T.J. (1981). Ethos and credibility: The construct and it measurement after three decades. Communication Studies, 32(1), 24-34. https:// doi.org/10.1080/10510978109368075

Men, L.R. (2012). CEO credibility, perceived organizational reputation, and employee engagement. Public Relations Review, 38(1), 171-173. https://doi.org/10.1016/j. pubrev.2011.12.011
Metzger, M.J., \& Flanagin, A.J. (2013). Credibility and trust of information in online environments: The use of cognitive heuristics. Journal of Pragmatics, 59, 210-220. https://doi.org/10.1016/j.pragma.2013.07.012

Minhas, L.S. (2017). Relation of managerial creativity and emotional intelligence to employee motivation commitment and performance. Journal of Psychosocial Research, 12(2), 255-2644.

Mubarak, M., \& Wan Yusoff, W. (2019). Impact of strategic leadership on organizational British Journal of Management and Marketing Studies, 2(1), 32-43. Retrieved from https://scholar.google.com/scholar?cluster=12166590636926819396\&hl= en\&as $s d t=2005 \&$ sciodt $=0,5$

Ndekugri, A., \& Greene, E. (2020). Individual approach to employee motivation: Is it worthwhile in the 21st century? International Journal of Global Business, 13(6), $16-24$.

Nduka, O. (2016). Employee motivation and performance. Doctoral thesis. Centria University of Applied Sciences. Retrieved from https://www.theseus.fi/ bitstream/handle/10024/120824/Employee motivation and performance.pdf? sequence $=1$

Osmani, M., Rozan, A., Zaidi, M., \& Nilashi, M. (2014). Motivational factors, trust and knowledge sharing in organizations. International Journal of Innovation and Scientific Research, 12(2), 463-474.

Ouakouak, M.L., \& Ouedraogo, N. (2013). The mediating role of employee strategic alignment in the relationship between rational strategic planning and firm performance: A European study. Canadian Journal of Administrative Sciences, 30(3), 143-158. https://doi.org/10.1002/cjas.1259

Pallant, J. (2010). SPSS survival manual. Berkshire: McGraw-Hill Education.

Paulo, M., \& Nunes, P. (2019). Implicit leadership theories in the context of frontex oint operations. Organizational Psychology and Organizational Behavior, 7(8), 49-74. https://doi.org/10.1146/annurev-orgpsych-012119-045434

Pokorny, M. (2013). Getting to know your employees and what motivates them. Employment Relations Today, 39(4), 45-52. https://doi.org/10.1002/ert

Porter, M.E. (1985). Competitive advantage. New York, NY: The Free Press.

Quick, J., \& Hall, S. (2015). The quantitative approach. Newsletter for AFPP Members, 25(10), 4. https://doi.org/10.7748/ns2012.12.27.15.52.c9485

Saunders, M., Lewis, P., \& Thornhill, A. (2007). Research methods for business students (4th edn.). London: Pearson Education.

Schniederjans, M., \& Cao, Q. (2009). Alignment of operations strategy, information strategic orientation, and performance: An empirical study. International Journal of Production Research, 47(10), 2535-2563. https://doi.org/10.1080/ 00207540701673465

Seidel, A., Saurin, T.A., Tortorella, G.L., \& Marodin, G.A. (2019). How can genera leadership theories help to expand the knowledge of lean leadership? Production Planning and Control, 30(16), 1322-1336. https://doi.org/10.1080/09537287. 2019.1612112

Shaikh, N.A. (2019). Leadership, manager motivation: Equal opportunity. Gale Academic Onefile, 38(12), 1-5

Shao, Z. (2019). Interaction effect of strategic leadership behaviors and organizational culture on IS-Business strategic alignment and Enterprise Systems assimilation. International Journal of Information Management, 44(13), 96-108. https://doi. org/10.1016/j.ijinfomgt.2018.09.010

Sousa, T.B., De Melo, I.C., De Oliveira, P.H., \& Lourenço, C.M. (2020). Balanced scorecard for evaluating the performance of supply chains: A bibliometric study. Journal of Engineering Research, 8(1), 294-313. https://doi.org/10.36909/jer. v8i1.4406

Street, C., Gallupe, B., \& Baker, J. (2018). The influence of entrepreneurial action on strategic alignment in new ventures: Searching for the genesis of alignment Journal of Strategic Information Systems, 27(1), 59-81. https://doi.org/10.1016/j. jsis.2017.06.002

Strobel, M., Tumasjan, A., Spörrle, M., \& Welpe, I.M. (2017). Fostering employees' proactive strategic engagement: Individual and contextual antecedents. Human
Resource Management Journal, 27(1), 113-132. https://doi.org/10.1111/17488583.12134

Sudnickas, T. (2019). Indicators' adequacy issues in performance measurement systems. Public Policy and Administration, 18(4), 524-533. https://doi.org/ 10.13165/VPA-19-18-4-11

Tabachnick, B.G., \& Fidell, L.S. (2007). Using multivariate statistics. Contemporary Psychology: A Journal of Reviews, 5, 28(8), 642. https://doi.org/10.1037/ 022267

Valeri, L., \& Vanderweele, T.J. (2013). Mediation analysis allowing for exposure Mediator interactions and causal interpretation: Theoretical assumptions and implementation with SAS and SPSS macros. Psychological Methods, 18(2), 137-150. https://doi.org/10.1037/a0031034

Van de Mortel, T.F. (2008). Faking it: Social desirability response bias in self-report research. Australian Journal of Advanced Nursing, 25(4), 40-48. Retrieved from http://www.ajan.com.au/ajan_25.4.html

Veldsman, D. (2017). Validating the psychological work immersion scale as a measure for predicting business performance. Doctoral dissertation. University of South Africa. Retrieved from http://uir.unisa.ac.za/handle/ 10500/22768

Veldsman, D., \& Coetzee, P.M. (2014). People performance enablers in relation to employees' psychological attachment to the organisation. Journal of Psychology 24(6), 480-486. https://doi.org/10.1080/14330237.2014.997028

Victor, J., \& Hoole, C. (2017). The influence of organisational rewards on workplace trust and work engagement. SA Journal of Human Resource Management, 15(1), 1-14. https://doi.org/10.4102/sajhrm.v15i0.853 
Von der Ohe, H., Martins, N., \& Roode, M. (2004). The influence of credibility on employeremployee trust relations. South African Jounral of Labour Relations, 28(2), 4-32.

Williams, R., Raffo, D.M., \& Clark, L.A. (2018). Charisma as an attribute of transformational leaders: What about credibility. Ournal of Management Development, 37(6), 512-524. https://doi.org/10.1108/JMD-03-2018-0088
Yiing, L.H., \& Ahmad, K.Z. (2009). The moderating effects of organizational culture on the relationships between leadership behaviour and organizational commitment and between organizational commitment and job satisfaction and performance. Leadership and Organization Development Journal, 30(1), 53-86. https://doi. org/10.1108/01437730910927106 